\title{
Why Fidelity Bank survived the banking crises in Ghana, but UT Bank collapsed: An explanation from Strategic Management
}

\section{Obi Berko O. Damoah}

University of Ghana Business School

\section{Majoreen Osafroadu Amankwah}

University of Ghana Business

School

\section{Robert Marshall Bennis}

Temple Advisory Consulting Accra, Ghana

\section{Correspondence:}

obodamoah@ug.edu.gh

obiberko@google.com moamankwah@ug.edu.gh cedinomics@gmail.com

University of Ghana Business School

P. O. Box LG 78, Legon, Accra, Ghana

https://dx.doi.org/10.4314/ajmr. v27i1.3

\begin{abstract}
The question of why some firms succeed whilst others fail even though they operate in the same industry, have similar sizes and face the same market conditions continue to attract research attention. Strategic management addresses this question in part and contends that the explanatory factors for such phenomenon is accounted for by how firms strategically align their internal capacity to the changing trends from their external environment especially political and competitive forces. The paper draws on two strategic management frameworks (i.e., PESTLE and Porter's five forces) to explain why Fidelity survived, but UT failed in the recent environmental turbulence which bedeviled the banking sector of Ghana though both started just about the same time and had similar size. In line with the assumptions of the two frameworks above, the present paper argues that the failure of UT bank and the survival of Fidelity Bank is accounted for by how each bank aligned its internal capacity to the regulatory and competitive forces that hit the banking industry. The paper employs secondary information (e.g., financial reports, web materials, newspaper articles), coupled with the PESTLE and Porter's five forces frameworks to explain the issue. The findings are that whilst the internal capacity of Fidelity Bank (e.g., its capital adequacy) was aligned to the regulatory demands of the Bank of Ghana, UT's internal conditions were so fragile that they failed to satisfy the regulator's demands in the deregulation. Following from the results of the study, implications on theory, practice and public policy are suggested.
\end{abstract}

Key words: Strategic management, UT Bank, Fidelity Bank, PESTLE, Porter's five forces 


\section{Introduction}

The paper uses two strategic management frameworks (PESTLE and Porter's five forces) to shed light on why Fidelity Bank Ghana Limited survived the recent banking crisis in Ghana whilst UT Bank collapsed. The paper conceptualizes the concept of "banking crises" in Ghana as the period when the Bank of Ghana increased the minimum capital requirement of banks from Ghc 120 million in 2013 to Ghc 400 million in 2017 by the Bank of Ghana leading to the collapsed of UT bank and Capital bank and consolidation of others (e.g., Construction bank, Biege bank, UniBank). The paper compares the two banks because they started approximately the same period, having similar size, operated in the same geographical market and faced the same market influences. In analyzing the event, the study dwells heavily on the political, legal/ regulatory and social cultural factors in the PESTLE model, coupled with two variables from Porter's five forces (rivalry among existing firms and threats of new entry). From a strategic management perspective, a firm's ability to strategically manage the PESTLE factors, especially political and legal and rivalry among firms as well threat of potential entrants by aligning their internal capacity and core competences predict to a higher degree, its probability of survival in times of crisis.

It is indicated that in August 142017, the Bank of Ghana (BoG) publicized in a press statement the cancelation of UT bank's Universal Banking license. The reason was that the UT Bank became deeply insolvent. Implicitly, the bank's liability exceeded their assets which meant that it was unable to pay off its obligations when they fall due from prudent financial mana- gement point of view. The Bank of Ghana indicated during a press conference that, UT Bank's plans to address their insolvency failed to meet the central bank's requirement. Consequently, a purchase and assumption agreement, a pro-forma balance sheet of liabilities and assets to be purchased were declared and a pool of bidders expressed interest. From BoG's perspective, GCB Bank was selected among three principal bidders to acquire the bank. It was told BoG took the decision because they saw that UT's continuous operations could have endangered not only their depositors' funds, but also presented a high degree of threat to the stability of the Ghanaian financial system. Therefore, the decision taken by BoG was meant to protect customers' funds and reinforce and fortify the financial sector of Ghana. GCB took over liabilities and selected assets of UT Bank (PwC, 2019; Citifmonline, 2017). From Bank of Ghana's viewpoint, this action was in line with the provisions contained in the section 123 of the Banks and Specialised Deposit-Taking Institutions (SDIs) Act, 2016 (Act 930).

The paper shows that from a strategic management viewpoint, UT failed, but Fidelity survived on the basis of how each of the banks was able to address the requirements from the Bank of Ghana using their internal capacity which is tantamount to the management of the PESTLE and Porter five forces frameworks. Strategic management is important because, of the various academic disciplines (e.g., human resource management, project management, finance), it is one of the core disciplines that focuses on a fit between a firm's internal operations vis-àvis their external influences. Conse- 
quently, strategic management concerns the strategies for aligning the internal activities of a firm to the changing trends in the external environment. Implicitly, managing strategically capitalizes on firms' internal capabilities in the most efficient and effective manner to generate competitive success for firms in the market place (Ulgen and Mirze, 2004). In strategic management, the method of aligning a fit between the internal and external operating environment is called strategy. Strategy is conceptualized as the rules and approaches that create a fit aimed at enhancing an organization's competitiveness in the marketplace (Thompson, Strickland, 2001). Compared to strategy, Hunger and Wheelen (2007) explained strategic management as allencompassing management decisions which accompany a number of strategic actions that determine the long-term performance of an organization in a competitive marketplace. Strategic management is needed because organizational managers need to predict the survival and sustainability of their institutions (Hamal and Prahalad, 1999).

As indicated above, the two frameworks which enable firms to understand the influences from the external environments are the PESTLE and Porter five forces (Pearce and Robbins, 2009; Porter, 1980). These frameworks convert the influences from the external environment (e.g., the recent regulations from Bank of Ghana that led to the consolidations of banks in Ghana) into a set of variables which then allow firms to strategically manage their external impacts. Consequently, organisations' ability to survive and remain sustainable depends to a large extent on how the external variables are properly managed using their internal capacity. Enormous benefits are derived when internal factors are strategically combined to deal with external influences.

Overall, the paper seeks to answer two main questions as follows.

1. To what extent does the PESTLE framework in strategic management explain the failure of UT and the survival of Fidelity Bank?

2. To what extent does Porter's five forces framework shed light on the collapse of UT and the survival of Fidelity?

To address these questions, the remaining of the paper is structured as follows. Section two presents the literature review while section three details the method, analysis and results. Section four looks at discussion, conclusions and implications.

\section{Literature Review}

\section{Overview of the Banking Sector in Ghana}

In 1989, the government of Ghana made policy changes in the financial sector and introduced the banking law known as the PNDC Law 225. In 2004, government introduced a new Banking Act and introduced changes in the minimum capital requirements, including the removal of secondary reserves. In 2008 after the Act, the minimum capital requirement for banks was increased to GHC 60 million and later increased to GHC120 million in 2013. In this period, some of the banks could not meet the minimum capital requirement and merged with others, whilst some were also acquired by other banks. Examples of such mergers in Ghana include The Trust Bank Limited (T'TB) and Ecobank, Intercontinental Bank and 
Access Bank etc. Flowing from this restructuring, the total banks in Ghana then was 27 universal banks with 16 owned by foreigners whilst the other 11 were owned by Ghanaians. Of this, six controlled approximately over half of the total assets in the financial sector (Aminatu, 2015). The introduction of the new Banking Act (i.e., Act 2016, Act 930) led to the flooding of the banking sector of Ghana by foreign banks, particularly hailing from Nigeria. For instance, the percentage of Nigerian banks which operated in the Ghanaian banking industry consisted of approximately $26 \%$ and this was because the minimum capital requirement in Ghana was moderately low as compared to similar capital requirement for establishing a bank in Nigeria.

\section{Overview of UT and Fidelity Bank}

The sub-section presents overview of the case banks to offer a reflection of what these banks have been doing in Ghanaian banking environment.

\section{UTBank}

UT Bank started as Best Financial Services in 1997 and was co-founded by Mr. Prince Kofi Amoabeng and $\mathrm{Mr}$ Joseph Nsonamoah, both Ghanaians. It started as a non-bank financial service providing quick financial assistances to prospective borrowers. Having established subsidiaries over time under the name UT Holding Limited, they got listed on the Ghana stock exchange in 2008 (www.utbankghana.com). In the same year, BPI Bank was acquired and in 2010, Unique Trust Financial services and UT Bank Ltd to become UT Bank Limited. While the bank's vision was "redefining banking," the mission was "the preferred bank for businesses and individuals to provide quality and outstanding products and services with speed and efficiency in order to generate customer satisfaction and build shareholder value". UT bank distinguished itself by being able to deliver financial products to customers in less than 48 hours with a slogan of "Unique Bank for Real People". UT bank had international affiliates in three countries, namely Germany, Nigeria and South Africa. The bank won the second most respected company and their $\mathrm{CEO}$ won the most respected CEO award for 2007 and 2010 (en.wikipedia.org/wiki/ UTBank).

\section{Fidelity Bank}

Fidelity Bank which started operating in October 1998 as a discount house and obtained license to work as a universal bank in 28 June 2006 is owned by Ghanaian and foreign individual institutional investors (ADB, SSNIT and its executives) (www.gipcghana.com/66-ghana-club$100 /$ company-profiles-2010/193fidelity-bank-ghana-limited.html).

Specifically, it was the $22^{\text {nd }}$ bank to be licensed by the Bank of Ghana (Banking Act, 2004, Act 673). The bank established Fidelity Asia Bank and acquired Procredit Saving and Loan Company limited in July 2012 and October 2014 respectively. Fidelity as a financial services group consists of Fidelity Bank Ghana Limited, Fidelity Asia Bank Limited and Fidelity Securities Limited. It is a Tier 1 bank and has the mission and vision of being among the leading three banks with international standards in Ghana and a worldclass financial institution that provides superior returns for stakeholders (shareholders, employees, customers, regulators, and community as a whole) (www. 
fidelitybank.com.gh/investors/aboutus).

\section{Conceptual Framework}

A number of strategic management tools can be used in analyzing the external environmental influences including the PESTLE framework, Porter's five forces and Porter's diamond (e.g. Pearce and Robbinson, 2009; David, 2013; Riasi, 2015). This study is limited to the first two frameworks (i.e., the PESTLE and Porter's five forces).

\section{The PESTLE framework}

Usually termed as PESTLE (Peace and Robinson, 2009), its elements can be broken down as: political-legal (P/L), sociocultural (S), economic (E), ecological (E), and technological (T). Pearce and Robbinson, 2009 argue creating and sustaining competitive advantage is a possibility with the continuous assessment of the external environment. Yuksel (2012) argues that no organization can survive in the long-run and remain profitable without considering the dynamic influences from the external environment. Therefore, addressing the external influences of an organization's external environment remains a core duty of every firm. Following Pearson and Robinson (2013), the PESTLE framework assists organizations to understand the external environment from the perspective of five variables. Although all the variables in the PESTLE framework is explained, this study draws more on the political and legal factors to shed light regarding why UT failed, but Fidelity survived.

\section{Political-legal}

The political/legal variable refers to the extent of government interventions in an economy. It consists of regulations that come from government ministry, agency and departments. Following Song, Sun and Jin (2017), examples of these factors include tax policies, trade policies, environmental laws that affect organizations positively or negatively in their quest to survive and be sustainable. The regulatory factors could be threats if they serve as constraints to the organisation's success. For instance, a case in point is the opening up of the banking system in Ghana for more private participation which led to the establishment of many indigenous and foreign banks. Consequently, such a move serves as an opportunity as well as a threat. Furthermore, the amendment of the Banking Act from Act 2004 (Act 678) to the new Banking Act 2007 (Act 738), coupled with the recapitalization by the Bank of Ghana are genuine political-legal factors which subsequently led to the collapse of many banks, including UT, the consolidation of many banks (e.g Biege Capital) and the collapse of many micro finance institutions.

\section{Economicfactors}

The economic factors refer to general variables such as interest rates and inflation that affect all organizations in a country. According to Koumparoulis (2013) these variables determine the capital accessibility, cost and demand of products. For instance, tax exemptions or increments, interest rates (high or low), the exchange rates (depreciation or appreciation of the cedi) can affect all organisations operating in particular country irrespective of their industry. The resultant effect of these factors is that a firm that is not placed strategically to address this issue cannot survive in the operating environment and therefore the alignment of one's internal 
factors to external economic factors determines why one firm survives while another collapses.

\section{Social cultural factors}

The social factors that affect a firm consists of the beliefs, values, attitudes, opinions, lifestyles and tastes and preferences as developed from cultural, ecological, demographic, religious, educational and ethnic conditioning (Pearce and Robbins, 2009). As social attitudes change, so does the demand for various types of products and this tends to reflect the behaviour and buying attitudes of citizens.

Koumparoulis (2013), further adds that these social factors are affected by fashion. Additionally, demographic trends have the potential of affecting the demand for products, hence these changes can serve as threats to any organization whose products appear to be outdated in regard to the changing attitudes. David (2013) has indicated that all organisations in any industry will stagger and be challenged by the opportunities and threats arising from changes in social, cultural, demographic and environmental variables, therefore a significant determinant of survival and otherwise.

\section{Technology}

Pearce and Robinson (2009) assert that organisations must accept technological change in order to avoid obsolescence and promote innovation. Accordingly, technological breakthrough might be a threat to existing industries if not taken advantaged off (Koumparoulis, 2013). Technological advancement may be sources of input enabling firms to become more efficient (Koumparoulis, 2013). However, the unavailability of funds to purchase the technology may be a threat to organisations that are not financially strong to acquire. For instance, an organisation's inability to acquire ATMs, cash depositing machines within the Ghanaian banking sector could make them followers instead of leaders in the industry if that becomes the technology of the day.

\section{Ecologicalfactors}

Ecology as noted by Pearce and Robbins, (2009) is the relationship among human beings and other living things (animals, water, land) and the air, soil and water. In a sense, organizations acquire their inputs from the environment, hence corporate survival and profitability of businesses partly hinges on policies from central government and non-governmental organisations. Concerning its management, governments are regulating these by ensuring that the ecology is protected through the passage of various laws. These laws sometimes can be more stringent than ever thereby putting pressure on organisations and so organisations that fail to adhere to these regulations are susceptible to bad reputation.

\section{Porter's five forces framework}

The five forces model, popularly called, the Porter's Five Forces describes the state of competition in every industry (Porter, 1980). Whilst all the variables in this model will be explained, the paper dwells on the rivalry among firms and the threat of competition to shed light on why UT failed, but Fidelity survived.

\section{Threats of New Entrants}

In every industry, this refers to new firms as potential competitors who are willing to enter the industry (Pearce and Robinson, 2009). Dess and Lumpkin (2003) add that 
profits of the established firms may be eroded by these entrants therefore, when new entrants are able to easily enter the industry, the degree of competition increases thereby posing a risk as well as threats to existing players. However, once new entrants are in the industry, the incumbents can also strategize by retaliating to discourage these potential entrants by either using substantial resources or cutting prices of their products in order to deter them, but this depends on the internal capacity of the firm. Also, incumbents may extend warranties, add features and offer financial specials. Related to this influence to the recent happening in the Ghanaian banking industry is the influx of large multinational foreign banks such as Zenith Bank and UBA from Nigeria. This had led to intense competition in Ghana's banking industry. Consequently, indigenous banks such as the UT bank lost their initial advantages such as offering loans to customers within 48 hours.

\section{Bargaining Power of Buyers}

Following Porter (2008), when these customers are large, they may threaten the players in the industry by forcing down prices and other significant changes that have high cost implications. Therefore, from the perspective of the model, this constitutes a threat that needs to be constantly monitored and managed (Pearce and Robinson, 2009; Porter, 2008; Indiatsy et al., 2014).

\section{Bargaining Power of Suppliers}

This variable consists of organizations that provide the materials, knowledge and information to grant a firm the needed resources required to produce goods and services (Martinez \& Wolverton, 2009). Suppliers of inputs (automated vending machine, labour etc) can put pressure on the organization by threatening to reduce the quality of inputs or increase the prices at which the supplies are sold. Karagiannopoulos et al. (2005) are of the view that supplier power mirrors that of the power buyers possess. Further, they opined that the analysis of supplier power usually concentrates on the relative numbers and concentration of suppliers relative to the industry players as well as the level of difference in the inputs they supply. Porter (2008) reiterated that powerful suppliers create more value for themselves by placing higher charges on the raw materials, limiting quality or services, or shifting costs to industry participants thereby making it a threat. Therefore, to survive and be profitable, the management of supplier power cannot be ignored in the industry.

\section{Threats of Substitutes}

According to Porter (2008), a substitute product that can be used by customers of the industry constitutes a threat to existing players. The substitutes although from a different industry can reduce the demand for a particular product if customers switch to these alternatives (Johnson et al, 2005). Karagiannopoulos et al. (2005) also argue that the threat of substitute poses a significant challenge on an organization's profitability. These substitutes can put a ceiling on the prices of products thereby increasing the intensity of competition (David, 2013). Consequently, this is a threat that no one can ignore because in combination to the above, they determine the success of a firm in an industry.

\section{Rivalry among existing competitors}

This variable refers to actions of existing players in the industry which pose as 
threats to other firms in the competitive struggle between organisations in an industry as they aim to capture market share from each other (Hill and Jones, 2007). Porter (2008) posits that already existing firms in an industry compete among themselves using forms such as new product introductions, advertising campaigns, price discounts and service improvement. Thus, the level to which rivalry influences the profit within the industry, first depends on the intensity of the competition and secondly on the basis on which they compete. Overall, firms that ignore the behaviour of their competitors risk failure because it determines their survival or failure in industry. As already indicated the influx of large multinational foreign banks such as Zenith Bank and UBA from Nigeria has heightened the competition among banks in Ghana. The banking sector is seen as one of the most competitive in the economy of Ghana. Despite the strict measures and policies put in place by the Bank of Ghana to restrict the number of participants in the industry (e.g., minimum capital requirement of 400 million Ghana Cedis), players in the industry continue to compete among themselves. Many have capitalized on technological innovations to deliver their services through platforms like automated teller machines (ATMs), ebanking, telephone banking, and SMS banking. For instance, when UT started, it was accorded one of the leading indigenous banks in Ghana and chalked lots of successes (e.g., in 2010, UT had 26 branches nationwide with Total Assets at the tune of $\mathrm{GH} \phi 516,177,000)$ yet all these advantages eroded due to the competition from other indigenous and foreign banks.

\section{Empirical literature}

Several studies have posited that the five forces explain the state of competition in an industry. Indiatsy et al.,'s (2014) study in Kenya in the banking sector and Wu et al., (2012) in Philippines show that these forces affect the attractiveness of an industry. In the case of Wu et al., findings were that while rivalry had the greatest impact on the firm's profitability, the threat by substitutes was key. This was followed by threats from new entrants and the bargaining power of buyers. Similarly, Smith (2008), used Porter's five forces model to conduct an industry analysis of 22 banks in the US to examine the online retail banking industry. Smith (2008) explained that economies of scale as an entry barrier can pose substantial hurdles to new players within the financial market. Further, technology has become a game changer in the current state of affairs within the industry, and as a result, larger and already existing banks no longer wield an advantage based on the economies of scale that were presented in the past. Smith (2008) also described powerful buyers as another important force in the process of analyzing the industry environment.

Boafo, Kraa and Webu (2018) assessed the impact of Porter's five forces on the performance of banks within the Ghanaian banking industry. Conveniently selecting Ecobank GH, Barclays Bank and Fidelity Bank, findings show that Porter's five forces significantly guide banks to strategically manage the state of their competition. The bargaining power of suppliers had the most effect on a bank's performance amongst all the five forces. Nonetheless, although the presence of telecommunication companies provide substitutes in the form of mobile money 
services, banks in Ghana have responded to it by adopting a strategy of linking up customer accounts to their mobile money account and have moved ahead to digitize their retail banking products in a bid to gain sustained competitive advantage.

\section{Methodology}

The study is a qualitative document analysis on two banks. In line with Corbin and Strauss (2008) and Rapley (2007), documents used were examined and interpreted before an understanding and empirical knowledge was gained. Following Bowen (2009), several documents can be employed in qualitative research which includes, but not limited to minutes of meetings, brochures, diaries, web materials, annual reports and newspapers. This study is based on annual reports and website information from UT and Fidelity bank. The data are content analyzed using Table 1 and Figure 1.

\section{Data from the Financial Reports and Web Information UTBank}

In the year 2000, Unique Trust had a total asset that exceeds GHC 1,500,000. UT bank was ranked as the best Non-Banking Financial Institution (NBFI) in 2003 by the Ghana Club 100. The total asset of Unique trust rose from GHC 55,316, 000 to GHC 120, 912,000 in 2006 to 2009 respectively. UT bank acquired majority shareholding in a Ghanaian Commercial bank called BPI Bank and became UT bank in 2008. Consequently, UT Bank was listed on the Ghana Stock Exchange the same year. The bank had 16 branches nationwide in 2009 and it increased to 26 branches in 2010 resulting in a total asset of GHC 516,177, 000. The report indicated that in 2011, the bank created and opened a subsidiary code-named as UT life. Again, during the Ghana Banking Awards which was held in 2011, several awards were won by UT bank (e.g., Bank of the Year 2011, Best Bank, IT/Electronic Banking, 1st Runner up- Customer Care, Retail Banking, Socially Responsible Bank and the 2nd Runner up Corporate Banking. In 2012, UT bank was adjudged the most respected company in Ghana. This was rated by the PricewaterhouseCoopers and B\&FT newspaper in Ghana.

\section{Fidelity Bank}

Total assets of the bank increased from 1,029,926 to 1,333,031 for 2011 to 2012 respectively while total equity also moved from 55,568 to 120,612 same year (Annual report, 2012). As at 2019, Fidelity bank's total assets stood at GHS10,478,022, a total equity of GHS 877,048 with 76 branches and over 1 million customers with an improvement from the previous year (assets, 7,015,823 and equity, 691,605) (Annual report, 2020; 2019). The bank offers a range of financial services including investment and personal banking and mortgages. The bank boasts of over 60 awards. From the Business and Financial Times Newspaper, in August 28, 2016 Fidelity Bank won the $15^{\text {th }}$ Edition of Ghana Banking awards. In this event, the bank was adjudged in the banking industry for 2015, including Corporate Social Responsibility Bank of the Year. At the 2015 edition of the Ghana Telecom Awards, Fidelity took three awards including the Best Bank in Mobile Financial Services and Best Bank Investment in ICT Infrastructure, while their Chief Information Officer took the Chief Information Officer of the Year. Again, the bank was adjudged the 2017 Best Local Bank and 
the Best Local Investment Bank for the fifth consecutive time in Ghana by EMEA Finance Limited. Other awards gained the same year are the Premium Quality Banking Service of the Year, (Entrepreneur Foundation of Ghana), Most Valuable Partner (Xpress Money), CIMG Bank of the Year (Chartered Institute of Marketing Ghana) (Annual report, 2018). Most recently (2019), the Bank received the Pioneering MoMo Partner Bank Award (Transaction \& Electronic Banking) MoMo Partner Bank Front Runner Award (Transaction \& Electronic Banking), Best Bank in Ghana (EMEA Banking Awards in London) and Best Bank in Ghana (The Banker Awards in London). Table 1 below summarizes the data above and compares the two banks.

Table 1: Similarities and differences between UT and Fidelity.

\begin{tabular}{|c|c|c|c|}
\hline Indicators & UT Bank & Fidelity & Similarities/differences \\
\hline Starting date & $\begin{array}{l}\text { Started } 1997 \text { as Unique } \\
\text { Trust Financial Services }\end{array}$ & $\begin{array}{l}\text { Started } 1998 \text { as } \\
\text { discount house }\end{array}$ & $\begin{array}{l}\text { Both started } \\
\text { approximately the same } \\
\text { year }\end{array}$ \\
\hline Ghana Club 100 Award & $\begin{array}{l}\text { UT was awarded the } \\
\text { best Non-banking } \\
\text { financial institution } \\
(\mathrm{NBFI})\end{array}$ & $\begin{array}{l}\text { No corresponding } \\
\text { activity as UT }\end{array}$ & $\begin{array}{l}\text { UT is ahead of Fidelity } \\
\text { in this case }\end{array}$ \\
\hline Total Asset in 2006 & $\begin{array}{l}\text { The total asset of } \\
\text { Unique trust rose to } \\
\text { GHC } 55,316,000\end{array}$ & $\begin{array}{l}\text { No corresponding } \\
\text { activity as UT }\end{array}$ & $\begin{array}{l}\text { UT is ahead of Fidelity } \\
\text { in this case }\end{array}$ \\
\hline Acquisition in 2008 & $\begin{array}{l}\text { Unique Trust acquired } \\
\text { BPI bank to become } \\
\text { UT bank in } 2008\end{array}$ & $\begin{array}{l}\text { Fidelity also did an } \\
\text { acquisition }\end{array}$ & $\begin{array}{l}\text { Fidelity also did an } \\
\text { acquisition along the line } \\
\text { by acquiring Procredit } \\
\text { in } 2014\end{array}$ \\
\hline $\begin{array}{l}\text { Listed on the Ghana } \\
\text { Stock Exchange }\end{array}$ & $\begin{array}{l}\text { In } 2008 \text {, the UT Ghana } \\
\text { was listed on the Ghana } \\
\text { Stock Exchange }\end{array}$ & $\begin{array}{l}\text { No corresponding } \\
\text { activity as UT }\end{array}$ & $\begin{array}{l}\text { UT was listed in the } \\
\text { Ghana Stock Exchange }\end{array}$ \\
\hline Total Asset in 2009 & $\begin{array}{l}\text { The total asset of } \\
\text { Unique Trust rose to } \\
\text { GHC } 120,912,000\end{array}$ & UT was higher & UT is ahead of Fidelity \\
\hline Total branches in 2009 & $\begin{array}{l}\text { UT bank had } 16 \\
\text { branches nation wide }\end{array}$ & UT bank was higher & $\begin{array}{l}\text { UT had more branches } \\
\text { than Fidelity at this time }\end{array}$ \\
\hline Total branches in 2010 & $\begin{array}{l}\text { UT branches increased } \\
\text { to } 26 \text { nation wide }\end{array}$ & $\begin{array}{l}\text { UT had more branches } \\
\text { at this time }\end{array}$ & $\begin{array}{l}\text { UT had more branches } \\
\text { compared to Fidelity }\end{array}$ \\
\hline Total assets in 2010 & $\begin{array}{l}\text { UTs total assets rose to } \\
\text { GHC } 516,177,000 \\
(\$ 89,309,121)\end{array}$ & $\begin{array}{l}\text { UT was higher in terms } \\
\text { of total assets }\end{array}$ & UT was ahead of Fidelity \\
\hline
\end{tabular}


Table 1 (continued)

\begin{tabular}{|c|c|c|c|}
\hline Indicators & UT Bank & Fidelity & Similarities/differences \\
\hline Ghana Banking Awards & $\begin{array}{l}\text { Won "bank of the year } \\
\text { award" at the } 11^{\text {th }} \text { edition } \\
\text { of Ghana Banking } \\
\text { Award (2011) }\end{array}$ & $\begin{array}{l}\text { 1. Won } 15^{\text {th }} \text { Edition of } \\
\text { Ghana Banking Award } \\
(2015) \\
\text { 2. Corporate Social } \\
\text { Responsibility Bank of } \\
\text { the Year (2015) }\end{array}$ & $\begin{array}{l}\text { Both won Ghana Banking } \\
\text { Awards at one time }\end{array}$ \\
\hline Most respected company & $\begin{array}{l}\text { 1. Won } 2^{\text {nd }} \text { Most } \\
\text { respected company } \\
\text { ward in } 2007 \\
\text { 2. Won Ghana's most } \\
\text { respected company } \\
\text { awards in } 2009\end{array}$ & $\begin{array}{l}\text { No corresponding } \\
\text { activity as UT }\end{array}$ & $\begin{array}{l}\text { Fidelity was not accorded } \\
\text { with the accolades of } \\
\text { most respected company } \\
\text { in Ghana }\end{array}$ \\
\hline $\begin{array}{l}\text { Most respected CEO } \\
\text { of UT }\end{array}$ & Won this in 2007,2010 & $\begin{array}{l}\text { No corresponding } \\
\text { event as UT }\end{array}$ & $\begin{array}{l}\text { None of Fidelity's CEOs } \\
\text { was publicly acclaimed as } \\
\text { the respect of Ghana }\end{array}$ \\
\hline Acquisition of a bank & BPI bank & $\begin{array}{l}\text { No corresponding } \\
\text { activity as UT }\end{array}$ & $\begin{array}{l}\text { Fidelity did not undertake } \\
\text { acquisition at this time }\end{array}$ \\
\hline $\begin{array}{l}\text { Profiled in a book of } \\
\text { Africa's greatest } \\
\text { entrepreneurs }\end{array}$ & $\begin{array}{l}\text { UT was profiled in a } \\
\text { book of Africa's greatest } \\
\text { entrepreneurs }\end{array}$ & $\begin{array}{l}\text { No corresponding } \\
\text { activity as UT }\end{array}$ & $\begin{array}{l}\text { Fidelity was not profiled } \\
\text { in a book of Africa's } \\
\text { greatest entrepreneurs }\end{array}$ \\
\hline $\begin{array}{l}\text { Best Local Bank and the } \\
\text { Best Local Investment } \\
\text { Bank }\end{array}$ & $\begin{array}{l}\text { UT bank did not receive } \\
\text { this type of award }\end{array}$ & $\begin{array}{l}\text { Fidelity started to } \\
\text { outperform UT } \\
\text { in } 2017\end{array}$ & Fidelity rising \\
\hline $\begin{array}{l}\text { MoMo Partner Bank } \\
\text { Front Runner Award }\end{array}$ & $\begin{array}{l}\text { UT bank did not receive } \\
\text { this type of award }\end{array}$ & Fidelity rising in 2019 & Fidelity rising \\
\hline $\begin{array}{l}\text { Best Bank in Ghana } \\
\text { (EMEA Banking Awards } \\
\text { in London) and Best } \\
\text { Bank in Ghana (The } \\
\text { Banker Awards in } \\
\text { London). }\end{array}$ & $\begin{array}{l}\text { UT bank did not receive } \\
\text { this type of award }\end{array}$ & Fidelity rising in 2019 & Fidelity rising \\
\hline
\end{tabular}

Source: Authors' own compilation from web information, financial statements of both banks (2006 - 2012) plus a presentation delivered by Robert M. Bennin, Executive Director, Temple Advisory on the Failure of UT and the Survival of Fidelity, April 2019

From Table 1 above, although both banks started around the same year, UT Bank had more awards and accolades compared to Fidelity Bank in the initial stages
(Column 2, Table 1). For example, Ghana Banking Awards, case topics in Business Schools, Most Respected Company, Most Respected CEO, and Profiled in a book on 
Africa's greatest entrepreneurs. Again, at the end of 2008, both banks had a similar balance sheet with UT bank having a Return of Equity almost double that of Fidelity Bank. At the end of another round of capitalization in the banking industry in 2012, UT had a higher equity position than Fidelity Bank. Yet regardless of the success that UT chalked (Table 1) the bank started to decline as Fidelity started to outperform UT. The Figure below is from the financial statements of both banks and presents their final performance.

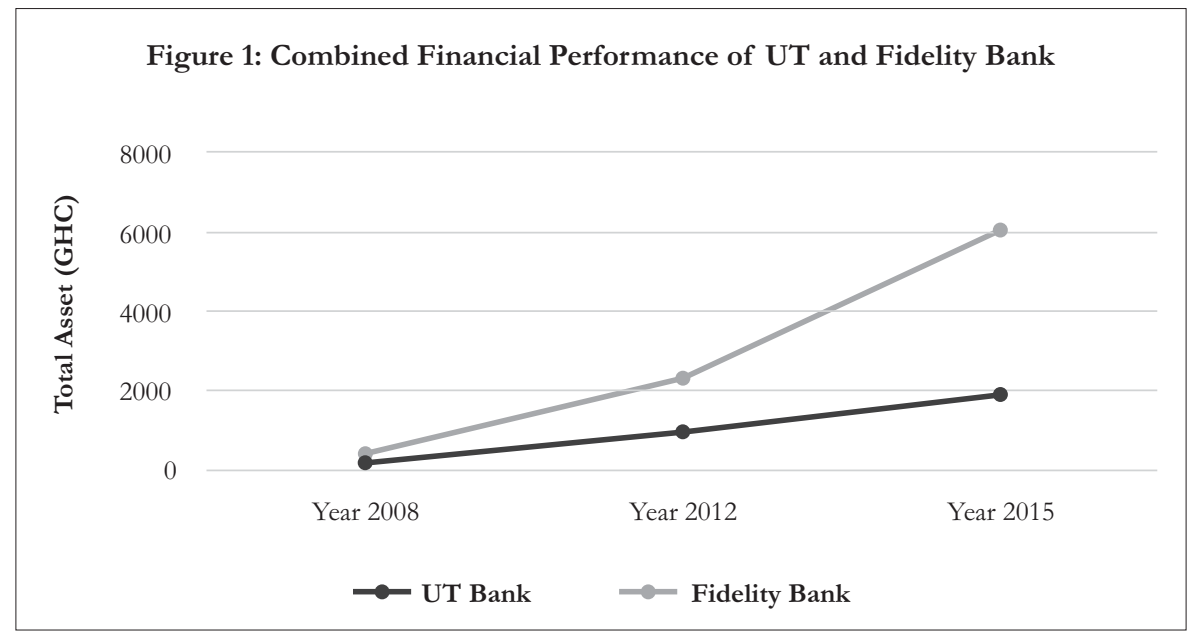

Sources: Financial statements of UT and Fidelity 2008 - 2015

\section{Discussion}

The results of the data from the respective financial statements showed that despite the numerous and impressive awards, UT started to decline and eventually collapsed. So, what made Fidelity to bypass UT even though they did not win all those impressive awards that UT won (Table 1). In this section we bring the two integrated conceptual frameworks from the literature review to explain the differences. The survival of Fidelity could be because of the alignment of their internal situation to suit the changing trends from the external environment. Implicitly, it was about effective management of PESTLE, especially the political and/or the regulatory influence which emanated from Bank of Ghana. Again, the influx of foreign banks in the Ghanaian banking environment (e.g., Nigerian banks), coupled with rivalry among the local players (Porter five forces) heightened the state of competition. UT started well, offering loans within 48 hours, but as the competition in the banking industry grew, their unique product got lost as they could not quickly innovate. However, for Fidelity to sail through to the point of meeting the Bank of Ghana's requirements without being collapsed or consolidated is an indication that their internal capacity aligned very well to both the competition and regulatory influence.

For instance, around year 2000, UT had a 
total asset of 1.5 million old Ghana Cedis and 2011, 11 years on had GHC560 million. Here the percentage difference is unimaginable (UTs Financial statements, 2000 \& 2011). So how can a firm have all these advantages (successes as presented in Table 1) and all of a sudden, sink into a demise? Until then Fidelity was nowhere near UT (Table 1), but now Fidelity is among the top 5 banks in Ghana and aims to be in the top 3. Meanwhile, they started operating fully in 2008 and in a space of 10 years, are in the top 5 banks in Ghana.

The explanatory factors are that first fidelity never lost sight of the politi$\mathrm{cal} /$ legal factors in the PESTLE model. For instance, the revocation of UT's license came from Bank of Ghana which was simply the management of a regulation, an external environmental issue which is a prediction from a strategic management perspective. There is therefore the need for companies to strategize in advance. For instance, it was indicated that when UT bank's liability exceeded their assets, they were asked to submit a restructuring and capital restoration plan aimed at addressing the insolvency. Yet it was indicated that the strategies submitted were found to be inadequate leading to its revocation. Consequently, UT failed to manage the regulatory issue initiated by BoG with their internal capacity, but Fidelity did. This is a clear indication that Fidelity ensured that its internal mechanisms constantly matched and aligned with the external influence (i.e. regulatory influence from Bank of Ghana). This confirms that the strategic management of the PESTLE framework is a key determinant of corporate survival.

Another critical factor was the socio- cultural factor in the PESTLE model. For instance, when UT changed to being a bank, it failed to adapt to the socio-cultural influences in the banking practice in Ghana. This is because the culture of giving loans ready in less than 48 hours implies that UT savings and loans was brought into UT banking services. However, it is being argued that in general, while salary loans can be processed within 48 hours, a meaningful corporate and investment loan cannot be concluded in 48 hours. Yet UT was providing all sorts of loans in 48 hours. Meanwhile the sociocultural characteristics of Ghanaians (PESTLE model) and the culture show that if an organization does not do serious due diligence on a loan application, it will likely go into bad loans. This is due to the probability of falsification of key information which is perceived to be common among Ghanaian loan applicants. Yet UT failed to adapt and continued with its old strategy, but Fidelity did otherwise and focused on the external environment and survived.

The implication here is that during the transition from the Savings and Loans Company to a bank, UT bank failed to adjust their vision to match their new banking status. They failed to realize the fact that they had migrated from the savings and loans industry into the banking industry with a different environment. This translates to mean that their competitors, customers, and creditors became different. It also meant that the political, economic, technological, ecological, and socio-cultural environment have changed and therefore they should have revised their plans to achieving their vision of providing quick loans. This is very critical because it shows that the management of 
UT bank did not consider the PESTLE analysis critically especially the sociocultural attitudes of Ghanaians and the regulatory influence.

Implicitly, without an understanding and application of the PESTLE model, it will be difficult for a firm to understand its market and survive in times of external pressure. This, Fidelity did perfectly; for instance, Fidelity started with both retail and corporate banking as well. It started with the concept of post office banking, just to get a bit of retail. When they realized that, that aspect was not really working, thereby learning by doing, they started agency banking, then to SMART account, trying to do everything possible and changing the strategy by understanding the market step-by-step (PESTLE and Porter five forces). This is strategic agility of applying the PESTLE which means studying the market and bringing up a product or idea. So, in effect, they were expanding their reach, acquired pro credit because pro credit had done such a great job with SMEs. Hence, after the merger, Fidelity had a branch network of 80, 96 ATMs, 300 agencies and 700,000 customers. They leveraged enablers, i.e. technology (digitization) and a contact center running since 2014 although there are banks today without contact centers. Fidelity understood the market (PESTLE) and built core capabilities to serve the market; they had an App, which could do anything (local, international, transfer, payment). Today people are not expected to visit the branch. In all these, Fidelity knew that capital was important, so they started building their capital base (aligning internal capacity to meet changing trends of the environment). As it was their mission to be in the top five banks, it will need to grow its capital, hence the recapitalization requirement was achieved as they had a capital of 270 million. Unfortunately, this is not the case for several banks that have been in existence for over 20 years. In conclusion, using the PESTLE model to understand the market in order to survive cannot be ignored.

In a liberalized economy, Porter's five forces model admonishes firms never to forget the threats of new entrants and embark on a deliberate strategy to combat them. Concerning rivalry, UT started with a unique advantage when it was a savings and loans company, but it was argued that fierce competition following the influx of large multinational foreign banks from Nigeria among others limited its success with respect to the size of deposits and market share. This is because these foreign competitors capitalize on their strong financial backing to outperform several local banks. Meanwhile, Fidelity survived the threats from these new entrants and the competition as it is currently among the top 5 banks in Ghana. Generally, it can also be argued that UT's collapse indicates that the Bank could not withstand competition in the banking industry. Implicitly coupled with its inability to meet the regulatory requirements, unlike Fidelity, its services became uncompetitive in line with competition among rival firms in the same industry. This case establishes the essence of environmental scanning. Through this process, organisations get to identify opportunities to be exploited and more importantly, threats to be defended against. Secondly, while strengths are identified and capitalized upon, weaknesses are minimized or improved.

Again, in Indiatsy et al's. (2014) study, the 
author's found that the application of Porter's five forces significantly improved the performance of banks in Kenya. This result parallels with Wu et al's., (2012) study in Philippines which found that Porter five forces affect the attractiveness of the industry. They provide evidence to show that the industry's profitability is impacted greatly with the most effect coming from rivalry, substitutes, threat from new entrants and bargaining power of buyers. Also, in a Ghanaian study that assessed the impact of Porter's five forces on the performance of banks within the Ghanaian banking industry, Boafo, Kraa and Webu (2018) confirm the findings that Porter's five forces significantly contri-buted to the performance of banks in Ghana by influencing profitability.

Another challenge which led to UT's demise could be poor diversification strategies. For instance, Universal Banking license means that all Tier 1 banks are allowed to do both retail, investment and mortgage banking. The mistake UT made was that it shifted depositors' funds into long-term financing options requiring longer maturity period. In their attempt to diversify their portfolios, they ventured into riskier territories that they had no systems and competencies to manage coupled with the granting of mortgage loans without first understanding that segment of the market. A deeper understanding of the external environment could have been possible using the PESTLE and the five forces models.

\section{Conclusion}

We believe that given the changes in our contemporary world, having market insights from the PESTLE and Porter five forces (i.e., knowing what is happening in your market) are critical. Consequently, managing strategically has become one of the strategic moves that companies cannot do without. Strategic management frameworks (e.g. Porter's five forces and PESTLE) give control to organizations to survive and remain sustainable from the influences of the external environment. Unlike Fidelity Bank, UT Bank collapsed because of its failure to understand and align its internal arrangements to the changing external environments using the strategic management tools above.

\section{Implications of the study}

External analysis from the strategic management discipline has been identified as a sine qua non for operational sustainability. The paper's main contribution is that the recent banking crises in the Ghanaian business environment lends credence to external validity of the strategic management framework, in particular, the PESTLE framework and Porter's five forces. The other contribution is that exploring the tenets of strategic management from an under researched context creates an opportunity for the understanding of the research community to be enhanced in terms of comparing results from the new geographical context to the more established geographical contexts (e.g. the western countries).

A key practical implication is that due to the changing trends in the banking industry, coupled with the on-going fierce competition, corporations especially banks must fortify, strengthen and re-establish their risk and compliant departments. Once these departments are established, employees must be trained to use the PESTLE and Porter's five force framework in external analysis. 


\section{REFERENCES}

Aminatu, M. (2015). The Impact of Integrated Financial Management System on Economic Development: The Case of Ghana. Korea Review of International Studies, 61-80.

Andriotis, K. (2004). Revising Porter's Five Forces Model for Application in the Travel and Tourism Industry. Tourism today.

Boafo, N. D., Kraa, J. J., \& Webu, C. G. (2018). Porter's Five Forces Impact on the Performance of Companies in the Banking Industry in Ghana. International Journal of Economics, Commerce and Management,4 (8),14-28.

Bowen, G. A. (2009). Document Analysis as a Qualitative Research Method. Qualitative Research Journal, 9(2), 27

Citifmonline, (2017). The rise and fall of UT, Capital. Available at:

http:/ / citifmonline.com/2017/08/therise-and-fall-of-ut-capital-bank. Accessed on $14^{\text {th }}$ July, 2019

Corbin, J. \& Strauss, A. (2008). Qualitative Research.

Cormican, K. \& O'Sullivan, D. (2004). Auditing best practice for effective product innovation management. Technovation, 24(10), 819-829.

David F. R. (2011). Strategic Management: Concepts and Cases. New Jersey, United States.

Dess, G. G., Lumpkin, G. T. \& Rivera Hernández, O. (2003). Dirección estratégica: creando ventajas competitivas.

Fidelity Bank, (2020) Available at: www.fidelitybank.com.gh/investors/about -us. Accessed on $2^{\text {nd }}$ September, 2020

Fidelity Bank Financial Reports (2020). Available at: https://www.fidelitybank. com.gh/downloadables/financial-reports. Accessed $12^{\text {th }}$ August, 2020

Ghana Investment Promotion Centre, (2010). Available at: www.gipcghana.com/66-ghana -club-100/company-profiles-2010/193fidelity-bank-ghana-limited.html. Accessed on 2nd September, 2020

Ghanaweb, (2020). Available at https://www. ghanaweb.com/GhanaHomePage/busines s/UT-Capital-Bank-were-defiant-BoG84414. Accessed on $11^{\text {th }}$ September, 2020

Grundy, T. (2006). Rethinking and Reinventing Michael Porter's Five Forces Model.
Strategic Change, 15(5), 213-229.

Hamel, G., \& Prahalad, C. K. (1994). Competing for the future. Harvard Business Review, 72(4), 122-128.

Hill, C. W. L. \& Jones, G. R. (2007). Strategic Management Theory: An Integrated Approach. Seventh edition. New York: Houghton Mifflin Company.

Indiatsy, C. M., Mwangi, M. S., Mandere, E. N., Bichanga, J. M., \& George, G. E. (2014). The Application of Porter's Five Forces Model on Organizational Performance: A case of Co-operative Bank of Kenya Ltd. European Journal of Business and Management, 6(16), 7585.

Kaplanov, N. (2012). Nerdy Money: Bitcoin, the Private Digital Currency, and the case against its regulation. Loy. Consumer L. Rev., 25,111

Karagiannopoulos, G. D., Georgopoulos, N., \& Nikolopoulos, K. (2005). Fathoming Porter's five forces model in the internet era. Info, 7(6), 66-76.

Koumparoulis, D. N. (2013). PEST Analysis: The Case of E-shop. International Journal of Economy, Management and Social Sciences, 2(2), 31-36.

Martinez, M., \& Wolverton, M. (2009). Innovative Strategy Making in Higher Education. IAP

McKinnon, R. I. (2010). Money and Capital in Economic Development. Brookings Institution Press.

Mirze, K. \& Ülgen, H. (2004). İșletmelerde stratejik yönetim. İstanbul: Literatür Yayınlar1.

Pearce, J. A. \& Robinson, R. B. (2005). Formulation, Implementation and Control of Competitive Strategy. McGraw-Hill.

Porter, M. E. (2008). The Five Competitive Forces that shape Strategy. Harvard Business Review, 86(1), 25-40.

PwC (2019) Ghana Banking Survey. Available at http://pwc.com. Accessed on 25th September, 2020

Rapley, T. (2007). Exploring Documents. Doing Conversation, Discourse and Document Analysis, 111-124.

Riasi, A. (2015). Competitive Advantages of the Shadow Banking Industry: An Analysis 
using Porter Diamond Model. Business Management and Strategy, 6(2), 15-27.

Smith, A. D. (2009). Internet Retail Banking: A Competitive Analysis in an increasingly financially troubled Environment. Information Management \& Computer Security, 17(2), 127150.

Song, J., Sun, Y. \& Jin, L. (2017). PESTEL Analysis of the Development of the Wasteto-energy Incineration Industry in China. Renewable and Sustainable Energy Reviews, 80, 276-289.

Thompson Jr, A. A. \& Strickland III, A. J. (1998). Strategic Management: Concepts and Cases.

Thurlby, B. (1998). Competitive Forces are also subject to change. Management Decision,
36(1), 19-24

Ulgen, H., \& Mirze, S. (2004). Strategic Management in Organizations, Baskr, Dstanbul. Literatur Pub. , No: 13, 3.

Wheelen, T. L., Hunger, J. D. \& Sánchez, M. Á. (2007). Administración estratégica y politica de negocios. Pearson Educación.

Wu, K. J., Tseng, M. L. \& Chiu, A. S. (2012). Using the Analytical Network Process in Porter's Five Forces Analysis-Case Study in Philippines. Procedia- Social and Behavioral Sciences, 57, 1-9.

Yüksel, I. (2012). Developing a Multi-criteria Decision-making Model for PESTEL Analysis. International Journal of Business and Management, 7(24), 52. 